\title{
Pengaruh Model Problem Based Learning Dengan Pendekatan Saintifik Terhadap Kemampuan Berpikir Kreatif Matematik Ditinjau Dari Self- Efficacy Siswa SMP
}

(The Effect Of Problem Based Learning Model With Scientific Approach To The Ability Of Mathematical Creative Thinking In Terms Of Self-Efficacy Mathematics In Students' SMP)

\author{
Catur Budi Nugroho ${ }^{1}$, Fahinu ${ }^{2}$, Asrul Sani $^{3}$ \\ ${ }^{1}$ Alumnus Prodi Pendidikan Matematika PPs Universitas Halu Oleo \\ ${ }^{2}$ Dosen Pendidikan Matematika FKIP dan PPs Universitas Halu Oleo; Co-author: fahinu@uho.ac.id \\ ${ }^{3}$ Dosen FMIPA dan Pendidikan Matematika PPs UHO
}

\begin{abstract}
Abstrak: Penelitian ini bertujuan untuk menggukapkan pengaruh model Problem Based Learning dengan pendekatan Saintifik terhadap kemampuan berpikir kreatif matematik ditinjau dari SelfEfficacy Matematis siswa. Populasi dalam penelitian ini adalah seluruh siswa kelas VII SMPN 07 Rarowatu Utara yang terdiri dari 3 kelas. Pengambilan sampel dalam penelitian ini menggunakan teknik Cluster Random Sampling. Model penelitian yang digunakan adalah Quasi Eksperimen dan desain penelitian yaitu Pretest Posttest Control Group Desain. Sampel dalam penelitian ini berjumlah 54 siswa. Instrumen penelitian yang digunakan, yaitu tes kemampuan berpikir kreatif matematik dan angket Self-Efficacy Matematis siswa. Data dianalisi dengan menggunakan statistik deskriptif dan statistik inferensial Hasil penelitian menunjukkan bahwa Ada pengaruh model Problem Based Learning dengan pendekatan Saintifik terhadap peningkatan kemampuan berpikir kreatif matematika siswa ditinjau dari Self-Efficacy. Secara signifikan ada perbedaan pengaruh model Problem Based Learning dengan pendekatan Saintifik lebih tinggi peningkatan kemampuan berpikir kreatif matematik siswa yang memiliki Self Efficacy matematis siswa pada kategori tinggi, sedang dan rendah. Sehingga dapat disimpulkan bahwa adanya pengaruh model Problem Based Learning dengan pendekatan Saintifik terhadap kemampuan berpikir kreatif matematik siswa ditinjau dari Self-Efficacy Matematis siswa pada kategori tinngi, sedang dan rendah.
\end{abstract}

Kata kunci: Problem Based Learning, Pendekatan Saintifik, Berpikir Kreatif, Self-Efficacy.

\begin{abstract}
This study aims to capture the influence of Problem Based Learning model with scientific approach to the ability of mathematical creative thinking in terms of students' SelfEfficacy Mathematics. The population in this study is all students class VII SMPN 07 Rarowatu Utara consisting of 3 classes. Sampling in this research using technique of Cluster Random Sampling. The research model used is Quasi Eksperimen and research design that is Pretest Posttest Control Group Design until this research amount to 54 students. Research instrument used, that is test of creative thinking ability of matematic and self-Efficacy Mathematical student questionnaire. Data analysis techniques used descriptive statistics and inferential statistics The results showed that there is an influence model of Problem Based Learning with a scientific approach to improving students' creative thinking ability mathematically viewed from SelfEfficacy. Significantly there are differences in the effect of Problem Based Learning model with higher scientific approach improvement of students 'creative thinking ability that has students' mathematical Self Efficacy on high, medium and low category. So it can be concluded that the influence of Problem Based Learning model with scientific approach to the ability of students' mathematical creative thinking in terms of Student Self-Efficacy on the category of high, medium and low.
\end{abstract}

Keywords: Problem Based Learning, Scientific Approach, Creativie Thinking, Self-Efficacy

\section{PENDAHULUAN}

Matematika merupakan ilmu yang menjelaskan konsep mulai dari yang abstrak, hingga yang terdefinisi dengan jelas. Hal ini karena matematika bukan berasal dari pengamatan, melainkan dari ide-ide, proses, dan pembuktian deduktif. Karena itu, banyak kemampuan berpikir matematika tingkat tinggi yang dapat 
dikembangkan saat mempelajari matematika.

Kemampuan berpikir kreatif adalah kemampuan memunculkan atau mengembangkan gagasan baru tanpa dibatasi oleh gagasan sebelumnya. Dengan mengembangkan kemampuan berpikir kreatif, diharapkan siswa memiliki penilaian diri yang baik terhadap kemampuan matematikanya.

Penilaian diri siswa terhadap kemampuan matematikanya merupakan salah satu aspek Self-Efficacy terhadap matematika. Dengan memiliki SelfEfficacy yang positif, siswa akan merasa lebih percaya diri dan pantang menyerah untuk menyelesaikan suatu masalah, termasuk masalah matematis yang menuntut kemampuan BKM

Permasalahan masih kurangnya kemampuan berpikir kreatif juga terjadi di SMPN 07 Rarowatu Utara Kabupaten Bombana khususnya kelas VII. Ditunjukkan pada Tabel 1 berikut.

Tabel 1. Hasil tes awal kemampuan berpikir kreatif matematika siswa

\begin{tabular}{lcl}
\multicolumn{1}{c}{ Aspek } & Peresentase & \multicolumn{1}{c}{ kreteria } \\
\hline kelancaran (Fluency) & $65 \%$ & Cukup \\
\hline Keluwesan (Flekxibility) & $49 \%$ & Kurang \\
\hline Keaslian (Originality) & $38 \%$ & Kurang \\
\hline Penguraian (Elaboration) & $41 \%$ & kurang \\
\hline
\end{tabular}

Hal ini menunjukkan bahwa di samping hasil tes dan fakta lain yang diperoleh secara garis besar bahwa siswa tidak dapat menjelaskan jawabannya secara terperinci dan lengkap ketika guru memberikan kesempatan untuk mempresentasikan hasil jawaban. Sedangkan kelancaran siswa dalam menyelesaikan masalah dengan tepat, melalui cara yang tidak baku atau luwes serta memerinci jawaban dengan cara berbeda dan idenya sendiri. Siswa terbiasa menyelesaikan soal-soal tersebut secara singkat dan langsung pada penyelesaiannya (to the point). Mereka tidak mengetahui bagaimana proses penyelesaiannya. Selain itu, siswa mengalami kesulitan dalam menyelesaikan soal-soal berbentuk soal cerita (soal aplikasi), kesulitan dalam membaca makna yang tersirat dan kesulitan konversi kedalam pernyataan matematika. Siswa lebih mudah memahami atau menyelesaikan soal-soal berbentuk konsep atau pengertian dengan hanya menghafal saja. Siswa tidak bisa untuk merumuskan masalah sendiri, mengemukakan ide-ide pendapatnya, mencari informasi dari berbagai sumber, dan mencari konsep dalam pembelajaran sendiri sehingga siswa tidak tertantang dan siswa tidak dapat berpikir kreatif dalam pembelajaran dan juga rasa ingin tahunya menjadi berkurang.

Rendahnya kemampuan berpikir kreatif matematis siswa yang terjadi disebabkan oleh pelaksanaan kegiatan pembelajaran yang dilakukan oleh Guru matematika adalah kurangnya inovatifnya guru dalam mengelola proses pembelajaran, kebanyakan guru matematika hanya menekankan pada penguasaan materi semata dan lebih banyak menjalin komunikasi satu arah dengan siswanya sehingga siswa kurang aktif dalam menyampaikan ide-idenya. Penumpukan informasi dari guru tersebut menjadikan model belajar siswa yang cenderung menghafal. Selain itu, kebanyakan guru matematika hanya mengutamakan hasil yang diperoleh tanpa melihat proses yang dilakukan siswa.

Proses penyampaian ide-ide untuk menyelesaikan masalah semuanya terabaikan dan tidak terlihat jika hasil yang didapat tidak sesuai dengan jawaban. 
Dalam pembelajaran matematika, siswa tidak dibiasakan untuk mendapat pemahaman dari pengalaman melalui proses identifikasi sifat-sifat yang dimiliki dan tidak dimiliki dari suatu objek matematikanya. Selain itu, siswa kurang terlatih dalam menyusun suatu permasalahan yang disajikan dan menemukan suatu konsep dalam memecahkan masalah matematika yang juga berakibat kurang ketrampilan siswa dalam melatih kemampuan berpikir kreatif matematikanya dan Soal terbuka (openended problem) merupakan soal yang memiliki beragam penyelesaian dan memungkinkan jawaban lebih dari satu sehinga dapat meningkatkan kemampuan berpikir kreatif dan akan menyerah begitu saja. Sikap mudah menyerah menunjukkan self-efficacy yang rendah.

Faktor yang mempengaruhi sebuah perilaku pada dasarnya berakar pada keyakinan bahwa mereka dapat mencapai target yang diharapkan. Keyakinan diri yang dimiliki oleh seorang individu terhadap kemampuannya untuk mengatasi hambatan guna mencapai tujuan yang diinginkan adalah Self-Efficacy. Dengan adanya Self-Efficacy, seseorang akan cenderung memilih tindakan yang membuat mereka merasa kompeten dan menghindari tindakan yang mereka anggap tidak dapat diselesaikan (Hidayat, 2011: 157).

Kemampuan berpikir kreatif merupakan salah satu alternatif untuk meningkatkan kemampuan berpikir kreatif dan self-efficacy siswa (Herman, 2007). PBL diawali dengan pemberian masalah atau situasi masalah yang kontekstual dan bermakna. Siswa kemudian diajak untuk memahami masalah tersebut dan mulai berpikir bagaimana cara menyelesaikan masalah yang diberikan dan melatih kepekaan terhadap masalah. Karena siswa menemukan sendiri ide untuk menyelesaikan masalah tersebut, penilaian siswa terhadap kemampuan matematikanya juga akan meningkat.
Suatu model pembelajaran yang baik akan lebih sempurna jika di dalamnya di integrasi suatu pendekatan. Dimana integrasi pendekatan ini semakin membuat kreativitas siswa dalam proses pembelajaran. dalam penelitian ini mengintegrasikan pendekatan saintifik dalam model PBL. Alasan pemilihan saintifik dikarenakan dalam pendekatan ini siswa tidak lagi dijadikan sebagai objek pembelajaran tetapi dijadikan sebagai subjek pembelajaran guru hanya sebagai fasilitator dan motivator saja. Sehingga proses tersebut memberikan kesempatan kepada siswa untuk mengembangkan kemampuannya serta dapat meningkatkan sikap positif dalam diri siswa.

Selanjutnya, proses membimbing penyelidikan individual maupun kelompok yang memungkinkan siswa saling bertukar jawaban dan menghasilkan solusi beragam (flexible) dari masalah yang ada dan ide yang disampaikan berasal dari dirinya sendiri (original). Kedua hal tersebut dapat meningkatkan kemampuan berpikir kreatif matematis siswa. Dengan melakukan diskusi kelompok, setiap siswa memperoleh pengalaman dengan orang lain selama pembelajaran. Siswa juga dilatih untuk menyampaikan pendapat dalam kelompoknya, sehingga kemampuan verbalnya juga meningkat. Hal tersebut dapat meningkatkan selfefficacy melalui PBL. Kemudian beberapa siswa menyajikan hasil diskusinya secara rinci dan lancar di hadapan temantemannya. Selain itu, pengalaman saat berdiskusi membuat siswa memiliki penilaian yang baik terhadap pencapaian kinerjanya.

Berdasarkan uraian tersebut, dapat dikatakan bahwa PBL diduga dapat meningkatkan kemampuan ber pikir luwes, original, terperinci, dan lancar terhadap masalah. Empat hal tersebut merupakan indikator kemampuan BKM. Dalam PBL, siswa juga meningkatkan penilaian diri terhadap kemampuan matematikanya, persuasi verbal, dan 
penilaian terhadap pencapaian kinerjanya. Aspek-aspek tersebut merupakan bagian dari self-efficacy siswa terhadap matematika. Dengan demikian, diduga bahwa pembelajaran berbasis masalah dapat meningkatkan kemampuan berpikir kreatif matematis dan self-efficacy siswa.

\section{METODE PENELITIAN}

Jenis Penelitian ini adalah merupakan eksperimen semua Quasi Experiment. Karena pada pelaksanaannya merupakan kelas eksperimen dan kelas kontrol serta penelitian dengan menggunakan preetest-posttest control group design. Rancangan desain yang akan digunakan dalam penelitian ini adalah Preetest - Posttest Control Group Design yang disajikan sebagai berikut:

$\begin{array}{llll}\mathrm{KE} & \mathrm{O}_{1} & \mathrm{X} & \mathrm{O}_{2} \\ \mathrm{KK} & \mathrm{O}_{3} & \mathrm{Y} & \mathrm{O}_{4}\end{array}$

Keterangan:

$\mathrm{KE}=$ Kelas eksperimen

$\mathrm{KK}=$ Kelas kontrol

$\mathrm{X}=$ Perlakuan, yaitu Model $P B L$

$\mathrm{Y}=$ Kontrol yaitu model pembelajaran Langsung

$\mathrm{O}_{1}=$ Pree-test siswa kelas eksperimen sebelum pembelajaran

$\mathrm{O}_{2}=$ Post-test siswa kelas eksperimen setelah pembelajaran

$\mathrm{O}_{3}=$ Pree-test siswa kelas kontrol sebelum pembelajaran

$\mathrm{O}_{4}=$ Post-test siswa kelas kontrol setelah pembelajaran

Metode penarikan sampel yang digunakan adalah cluster random sampling. Langkah-langkah pengambilan sampel penelitian adalah sebagai berikut:

(1) Peneliti memilih populasi penelitian yaitu siswa kelas VIII SMP Negeri 07 Rarowatu Utara yang terdiri dari tiga kelas paralel, (2) Sampel diambil berdasarkan teknik pengambilan sampel Cluster Random Sampling yaitu mengambil dua kelas paralel yang homogen dan mempunyai kemampuan yang relatif sama. berdasarkan hasil uji homogenitas pada Tabel 3.2, terdapat dua
Tujuan penelitian ini adalah untuk mengetahui peningkatan kemampuan berpikir kreatif matematis dan self-efficacy siswa melalui pembelajaran berbasis masalah.

kelas yang homogen yaitu kelas VIII.A dan VIII.B pada taraf signifikansi $\alpha=$ 0,05 , (3) dari dua kelas yang homogen, kemudian dilakukan pengacakkan kelas sehingga diperoleh kelas VIII.A menjadi kelas eksprimen dan VIII.B menjadi kelas Kontrol kedua.

Dalam penelitian ini, instrumen yang digunakan untuk mengumpulkan data adalah instrumen tes dan instrumen non tes. Instrumen tes berupa tes kemampuan berpikir kreatif dan instrumen non tes berupa angket skala Self-Efficacy Matematis.

Uji Perbedaan Rata-Rata

Peningkatan Kemampuan Berpikir Kreatif Ditinjau dari Self-Efficacy Matematis Siswa (Secara Menyeluruh). Untuk menguji adanya perbedaan peningkatan kemampuan berpikir kreatif siswa ditinjau dari self-efficacy Matematis siswa secara menyeluruh pada kelas kontrol dan kelas eksperimen digunakan analisis uji-F (two way anova) Rancangan Acak Kelompok (RAK) dengan taraf signifikansi 0,05. Kriteria pengujian yakni jika nilai sig. > $\alpha=0.05$ maka $\mathrm{H}_{0}$ diterima. Artinya semua perlakuan tidak berpengaruh terhadap respon yang diamati. Rumusan hipotesis yang akan diuji adalah :

$\mathrm{H}_{0}: \mu_{1}=\mu_{2}$ lawan

$\mathrm{H}_{1}: \mu_{1} \neq \mu_{2}$

Keterangan:

$\mu_{1}$ : Rata-rata peningkatan kemampuan berpikir kreatif siswa kelompok eksperimen yang mendapat model $P B L$ menggunakan pendekatan Saintifik

$\mu_{2}$ : Rata-rata peningkatan kemampuan berpikir kreatif siswa kelompok 
kontrol yang mendapat model langsung menggunakan pendekatan Saintifik.

Uji Perbedaan Rata-Rata Peningkatan Kemampuan Berpikir Kreatif Ditinjau dari Self-Efficacy Matematis Siswa (Secara Parsial). Hipotesis dengan faktor khusus (Self-Efficacy Matematis) terdiri atas tiga hipotesis dan untuk mengujinya menggunakan statistik uji $\mathrm{t}$ untuk data tidak berpasangan (independent t-test) dengan kriteria jika nilai sig. > $\alpha=0.05$, maka $\mathrm{H}_{0}$ diterima. Artinya tidak

\section{HASIL}

Penguji terhadap perbedaan peningkatan kemampuan berpikir kreatif siswa ditinjau dari Self-Efficacy Matematis siswa secara menyeluruh pada kelas kontrol dan kelas eksperimen digunakan analisis uji-F (two way anova) Rancangan Acak Kelompok (RAK) dengan taraf signifikansi 0,05 . Kriteria pengujian yakni jika nilai sig. $>\alpha=0.05$ maka $\mathrm{H}_{0}$ diterima. Artinya semua perlakuan tidak ada perbedaan rata-rata kemampuan berpikir kreatif siswa pada siswa yang diajar dengan model $P B L$ menggunakan pendekatan Saintifik dan langsung menggunakan pendekatan Saintifik ditinjau dari siswa yang memiliki Selfefficacy Matematis tinggi, sedang dan rendah. Kriteria: Ho di tolak jika nilai sig $<\alpha=0,05$ atau $t_{\text {tabel }} \leq t$ hitung, sebaliknya Ho diterima jika nilai sig. $\geq \alpha=0,05$

berpengaruh terhadap respon yang diamati.

Sebelum dilakukan uji hipotesis, terlebih dahulu data yang digunakan akan diuji prasarat yakni uji homogenitas dan uji normalitas, diperoleh $\mathrm{N}$-Gain data eksperimen dan kontrol bersifat homogen dan berdistribusi normal. Karena memenuhi kedua uji prasyarat, maka uji hipotesis dapat dilanjutkan dengan uji two way anava. Hajil uji tersebut disajikan pada Tabel 2 berikut.

Tabel 2. Uji Perbedaan Rata-Rata Data N-Gain KBKM Siswa Kelas Eksperimen dan Kelas Kontrol Ditinjau Dari SE Matematis Siswa

\begin{tabular}{lcccccc}
\hline \multicolumn{1}{c}{ Source } & $\begin{array}{c}\text { Type III Sum of } \\
\text { Squares }\end{array}$ & df & $\begin{array}{c}\text { Mean } \\
\text { Square }\end{array}$ & F & Sig. & $\begin{array}{c}\text { Partial Eta } \\
\text { Squared }\end{array}$ \\
\hline $\begin{array}{l}\text { Corrected } \\
\text { Model }\end{array}$ & $.329^{\mathrm{a}}$ & 3 & .110 & 95.485 & .000 & .851 \\
Intercept & 4.541 & 1 & 4.541 & 3952.06 & .000 & .988 \\
KELAS & .131 & 1 & .131 & 114.300 & .000 & .696 \\
SE & .218 & 2 & .109 & 94.827 & .000 & .791 \\
Error & .057 & 50 & .001 & & & \\
Total & 4.929 & 54 & & & & \\
Corrected & .387 & 53 & & & & \\
Total & & & & & & \\
\hline a R Squared & & & & & & \\
\hline
\end{tabular}

a. $\mathrm{R}$ Squared $=.851$ (Adjusted R Squared $=.842$ )

Dari hasil analisis pada Tabel 2, terlihat bahwa pada baris kelas nilai $F_{\text {hitung yang diperoleh sebesar } 114,300}$ dan nilai signifikasinya adalah 0,000 . Nilai signifikasi tersebut lebih kecil dari taraf signifikansi $\alpha=0,05$, maka kesimpulan hipotesis adalah menolak $H_{0}$. Hal ini berati bahwa terdapat perbedaan yang 
signifikan rata-rata peningkatan kemampuan berpikir kreatif matematik siswa yang diajar dengan model PBL dengan pendekatan saintifik dan siswa yang diajar dengan model pembelajaran langsung mengunakan pendekatan saintifik ditinjau dari Self-Efficacy matematis siswa.

Hipotesis dengan faktor khusus (Self-Efficacy Matematis) terdiri atas 3 hipotesis dan untuk mengujinya menggunakan statistik uji $\mathrm{t}$ untuk data tidak berpasangan (independen $t$-test) dengan kereteria jika nilai sig. $>\alpha=$ 0,05, maka $H_{0}$ diterima.

\section{$>$ Hipotesis 1}

Uji hipotesis berdasarkan SelfEfficacy yang dipakai adalah uji t. Hipotesis 1 dinyatakan bahwa: Rata-rata peningkatan kemampuan berpikir kreatif matematika siswa yang diajar dengan model pembelajaran PBL dengan pendekatan Saintifik lebih tinggi disbanding siswa yang diajar dengan model pembelajaran langsung dengan pendekatan Saintifik khusus untuk siswa yang memiliki Self-Efficacy matematis tinggi. Hipotesis statistiknya adalah sebagai berikut:

$$
\begin{aligned}
& \mathrm{H}_{0}: \mu_{1 S E T}=\mu_{2 S E T}, \text { lawan } \\
& \mathrm{H}_{1}: \mu_{1 S E T} \neq \mu_{2 S E T}
\end{aligned}
$$

Kriteria $\mathrm{H}_{0}$ ditolak jika nilai $-\mathrm{t}$ hitung < $\mathrm{t}_{\text {tabel }}<\mathrm{t}_{\text {hitung }}$ atau nilai sign $<\alpha=0.05$, sebaliknya $\mathrm{H}_{0}$ diterima. Hasil perhitungan uji-t ini selengkapnya hasil analisis uji-t kedua kelompok data tersebut juga disajikan pada Tabel 3.

Tabel 3. Uji perbedaan Dua Rata-rata Data $\mathrm{N}$-Gain KBKM Kelompok Eksperimen

\begin{tabular}{|c|c|c|c|c|c|c|c|c|c|}
\hline \multicolumn{10}{|c|}{ hdependent Samples Test } \\
\hline & \multicolumn{2}{|c|}{$\begin{array}{c}\text { Levena's Testtor Equaliny of } \\
\text { Varianoas }\end{array}$} & \multicolumn{7}{|c|}{ tesifor Equalty of Neans } \\
\hline & \multirow[b]{2}{*}{ F } & \multirow[b]{2}{*}{ Sig. } & \multirow[b]{2}{*}{$t$} & \multirow[b]{2}{*}{ df } & \multirow[b]{2}{*}{$\operatorname{Sig} .(2 \cdot \operatorname{ag} \mid 20)$} & \multirow{2}{*}{$\begin{array}{c}\text { Mean } \\
\text { Dfereno: }\end{array}$} & \multirow{2}{*}{$\begin{array}{l}\text { Sid. Emor } \\
\text { Diferenos }\end{array}$} & \multicolumn{2}{|c|}{$\begin{array}{c}\$ \$ \% \text { Corfdenwe hieral of the } \\
\text { Diferenos }\end{array}$} \\
\hline & & & & & & & & Loner & Upper \\
\hline N_GHN_EXS_KONT_SE_TNGGil Equal rarianoes assuned & 1.558 & .182 & 10.612 & 15 & $0: 0$ & .15958 & 015015 & .12761 & .19175 \\
\hline Equal iariances noi assumet & & & & 14.884 & 0.0 & .15988 & 01413 & .12856 & .18530 \\
\hline
\end{tabular}
dan Kelompok kontrol Khusus Self efficacy Tinggi

Dari hasil analisis pada Tabel 3 tersebut, terlihat juga bahwa nilai $\mathrm{t}$ dengan degree of fredom atau $\mathrm{df}=15$ sebesar 10,612 dan Sig. $(2-$ tailed $)$ adalah $0,000 / 2=0,000$. Nilai sig. ini lebih kecil dari taraf signifikan $\alpha=0,05$ yang ditetapkan, sehingga kesimpulan hipotesis menolak $H_{0}$. ini berati bahwa rata-rata peningkatan kemampuan berpikir kreatif matematik siswa yang diajar dengan model pembelajaran PBL dengan pendekatan Saintifik lebih tinggi dibanding siswa yang diajar dengan model pembelajaran langsung dengan pendekatan Saintifik khusus untuk siswa yang memiliki Self-Efficacy Matematis tinggi

\section{Hipotesis 2}

Uji hipotesis berdasarkan SelfEfficacy yang dipakai adalah uji t. Hipotesis 2 dinyatakan bahwa: Rata-rata peningkatan kemampuan berpikir kreatif matematik siswa yang diajar dengan model pembelajaran PBL dengan pendekatan Saintifik lebih tinggi disbanding siswa yang diajar dengan model pembelajaran langsung menggunakan pendekatan saintifik khusus untuk siswa yang memiliki Self-Efficacy matematis sedang". Hipotesis statistiknya adalah sebagai berikut:

$$
\begin{aligned}
& \mathrm{H}_{0}: \mu_{1 S E S}=\mu_{2 S E S}, \text { lawan } \\
& \mathrm{H}_{1}: \mu_{1 S E S} \neq \mu_{2 S E S}
\end{aligned}
$$


Kriteria $\mathrm{H}_{0}$ ditolak jika nilai $-\mathrm{t}$ hitung $<$ $\mathrm{t}_{\text {tabel }}<\mathrm{t}$ hitung atau nilai sign $<\alpha=0.05$, sebaliknya $\mathrm{H}_{0}$ diterima. Hasil perhitungan uji-t ini selengkapnya hasil analisis uji-t kedua kelompok data tersebut juga disajikan pada Tabel 4 ..

\section{Tabel 4. Uji Data Perbedaan Dua Rata-rata Data $N$-Gain KBKM Kelompok Eksperimen dan Kelompok kontrol Khusus Self-Efficacy Sedang}

Independent Samples Test

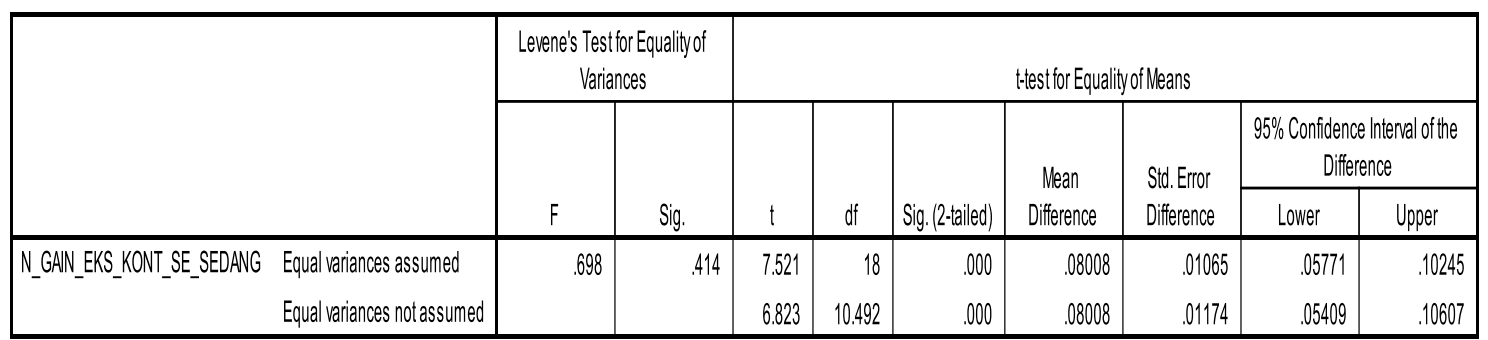

Dari hasil analisis pada Tabel 4.14 tersebut, terlihat juga bahwa nilai $\mathrm{t}$ dengan degree of fredom atau $\mathrm{df}=18$ sebesar 7,521 dan Sig. $(2-$ tailed $)$ adalah $0,000 / 2=0,000$. Nilai sig. ini lebih kecil dari taraf signifikan $\alpha=0,05$ yang ditetapkan, sehingga kesimpulan hipotesis menolak $H_{0}$. ini berati bahwa rata-rata peningkatan kemampuan berpikir kreatif matematik siswa yang diajar dengan model pembelajaran PBL dengan pendekatan Saintifik lebih tinggi dibanding siswa yang diajar dengan model pembelajaran langsung dengan pendekatan Saintifik khusus untuk siswa yang memiliki Self-Efficacy Matematis sedang.

\section{Hipotesis 3}

Uji hipotesis berdasarkan SelfEfficacy yang dipakai adalah uji t.
Hipotesis 2 dinyatakan bahwa: Rata-rata peningkatan kemampuan berpikir kreatif matematika siswa yang diajar dengan model pembelajaran PBL dengan pendekatan Saintifik lebih tinggi disbanding siwa yang diajar dengan model pembelajaran langsung menggunakan pendekatan Saintifik khusus untuk siswa yang memiliki Self-Efficacy matematis rendah". Hipotesis statistiknya adalah sebagai berikut:

$$
\begin{aligned}
& \mathrm{H}_{0}: \mu_{1 S E R}=\mu_{2 S E R}, \text { lawan } \\
& \mathrm{H}_{1}: \mu_{1 S E R} \neq \mu_{2 S E R}
\end{aligned}
$$

Kriteria $\mathrm{H}_{0}$ ditolak jika nilai $-\mathrm{t}_{\text {hitung }<}$ $\mathrm{t}_{\text {tabel }}<\mathrm{t}$ hitung atau nilai sign $<\alpha=0.05$, sebaliknya $\mathrm{H}_{0}$ diterima. Hasil perhitungan uji-t ini selengkapnya hasil analisis uji-t kedua kelompok data tersebut juga disajikan pada Tabel 5 .

\section{Tabel 5. Uji Data Perbedaan Dua Rata-rata Data $N$-Gain KBKM Kelompok Eksperimen dan Kelompok Kontrol Khusus Self-Efficacy Rendah}

\begin{tabular}{|c|c|c|c|c|c|c|c|c|c|}
\hline & $\begin{array}{r}\text { Levene's Test } \\
\text { Varia }\end{array}$ & Equalityof & \multicolumn{7}{|c|}{ t:test for Equalityof Means } \\
\hline & \multirow[b]{2}{*}{$\mathrm{F}$} & \multirow[b]{2}{*}{ Sig. } & \multirow[b]{2}{*}{$t$} & \multirow[b]{2}{*}{$d f$} & \multirow[b]{2}{*}{ Sig.(2-tailed) } & \multirow{2}{*}{$\begin{array}{c}\text { Mean } \\
\text { Difference }\end{array}$} & \multirow{2}{*}{$\begin{array}{l}\text { Std. Error } \\
\text { Difference }\end{array}$} & \multicolumn{2}{|c|}{$\begin{array}{c}95 \% \text { Confidence Interval of the } \\
\text { Difference }\end{array}$} \\
\hline & & & & & & & & Lower & Upper \\
\hline N_GAN_EKS_KONT_SE_RENDAH Equal variances assumed & .145 & .708 & 1.233 & 18 & .233 & .02197 & .01782 & .01547 & .05941 \\
\hline Equal variances notassumed & & & 1.237 & 15.329 & .235 & .02197 & .01776 & 0,01581 & .05975 \\
\hline
\end{tabular}

Independent Samples Test 
Dari hasil analisis pada Tabel 4 tersebut, terlihat juga bahwa nilai t dengan degree of fredom atau $\mathrm{df}=18$ sebesar 1,233 dan Sig. $(2-$ tailed $)$ adalah $0,233 / 2=0,116$. Nilai sig. ini lebih besar dari taraf signifikan $\alpha=0,05$ yang ditetapkan, sehingga kesimpulan hipotesis terima $H_{0}$. ini berati bahwa rata-rata peningkatan kemampuan berpikir kreatif

\section{PEMBAHASAN}

Self-Efficacy adalah kepercayaan diri terhadap kemampuan memrepresentasikan dan menyelesaikan masalah matematika, cara belajar/bekerja dalam memahami konsep dan menyelesaikan tugas, dan kemampuan berkomunikasi matematika dengan teman sebaya dan pengajar selama pembelajaran.

Bandura (1997) menjelaskan bahwa, Self-Efficacy akan mempengaruhi tindakan, upaya, ketekunan, fleksibilitas dalam perbedaan, dan realisasi dari tujuan dari individu ini, sehingga Self-Efficacy yang terkait dengan kemampuan seseorang seringkali menentukan outcome sebelum tindakan terjadi. Menurut Bandura, SelfEfficacy merupakan konstruksi sentral dalam teori kognitif sosial yang dimiliki seseorang yang akan mempengaruhi pengambilan keputusannya dan mempengaruhi tindakan yang akan dilakukannya, seseorang akan cenderung menjalankan sesuatu apabila ia merasa kompoten dan percaya diri, dan akan menghindarinya apabila tidak; Membantu seberapa jauh upaya ia bertindak dalam suatu aktivitas, berapa lama ia bertahan apabila mendapat masalah dan seberapa fleksibel dalam suatu situasi yang kurang menguntungkan baginya, dalam hal ini makin besar Self-Efficacy seseorang maka makin besar upaya ketekunan dan fleksibilitasnya; mempengaruhi pola pikir dan reaksi emosionalnya. Seseorang dengan Self- Efficacy yang rendah mudah menyerah dalam menghadapi masalah, cenderung menjadi stress, depresi dan mempunyai suatu visi yang sempit tentang matematik siswa yang diajar dengan model pembelajaran PBL dengan pendekatan Saintifik lebih rendah dibanding siswa yang diajar dengan model pembelajaran langsung dengan pendekatan Saintifik khusus untuk siswa yang memiliki Self-Efficacy Matematis rendah

apa yang terbaik untuk menyelesaikan masalah itu. Sedangkan Self-Efficacy yang tinggi akan membantu seseorang dalam menciptakan suatu perasaan tenang dalam menghadapi masalah atau aktivitas yang sukar.

Tujuan dari penelitian ini adalah untuk menganalisis dan mengkaji secara komprehensif perbedaan peningkatan kemampuan berpikir kreatif matematis ditinjau dari Self-Efficacy siswa antara siswa kelas eksperimen yang mengikuti model pembelajaran $P B L$ dengan pendekatan Saintifik dan kelas kontrol yang mengikuti model pembelajaran langsung dengan pendekatan Saintifik. Selain itu, dianalisis pula proses pembelajaran terhadap penggunaan pembelajaran dari kedua kelas tersebut.

Data dalam penelitian ini terdiri atas data kualitatif dan data kuantitatif. Data kualitatif diperoleh dari hasil observasi selama proses pembelajaran. Sedangkan data kuantitatif diperoleh dari hasil preetes dan posttest kemampuan berpikir kreatif matematika, serta skala Self-Efficacy pada kelas eksperimen dan kelas kontrol.

Pada awalnya, sebelum peneliti melakukan pemberian treatment berupa model pembelajaran PBL dengan pendekatan saintifik, terlebih dahulu dilakukan pretest kemampuan berpikir kreatif matematika dan diberi angket SelfEfficacy. Kemudian diberi perlakuan berupa pembelajaran yang berbeda pada masing-masing kelas, lalu dilakukan posttest kemampuan berpikir kreatif matematika. Hasilnya dianalisis dan 
dilaporkan dalam laporan hasil penelitian ini.

Data dari 2 kelas sampel penelitian dianalisis secara deskriptif dan inferensial untuk menjawab permasalahan penelitian ini. Pada analisis deskriptif dikemukakan nilai yang diperoleh siswa dari hasil pretest, posttest, angket Self-Efficacy, serta peningkatan kemampuan siswa pada setiap variabel yang diteliti dan berbagai faktor yang mempengaruhinya. Sedangkan pada analisis inferensial dikemukakan hasilhasil pengujian hipotesis baik untuk mengungkap perbedaan peningkatan kemampuan berpikir kreatif matematis ditinjau dari Self-Efficacy antara kelas yang diberi perlakuan berupa model pembelajaran $P B L$ dengan pendekatan saintifik dan pembelajaran langsung dengan pendekatan saintifik.

Penelitian ini melibatkan dua kelompok siswa yang berbeda, sehingga analisis statistic yang digunakan adalah uji perbedaan rata-rata $N$-Gain kemampuan berpikir kreatif matematik ditinjau dari Self-Efficacy, dilakukan dengan melakukan uji perbedaan rata-rata independen sampel t-test jika persyaratan uji-t dipenuhi. Sebelum dilakukan analisis, terlebih dulu dilakukan uji normalitas dan uji homogenitas varians populasi. Untuk uji normalitas distribusi data digunakan uji kolmogrov-smirnof, dan uji homogenitas varians populasi menggunakan uji lavene. Analisis data kemampuan berpikir kreatif matematika ditinjau dari Self-Efficacy serta penjelasan disajikan secara rinci seperti berikut.

Dari hasil analisis pada Tabel 2 pada baris Self-Efficacy matematis, diperoleh nilai $F_{\text {hitung }}$ yang diperoleh sebesar 94,827 dan nilai signifikasinya adalah 0,000 . Nilai signifikasi tersebut lebih kecil dari taraf signifikansi $\alpha=0,05$, maka kesimpulan hipotesis adalah menolak $H_{0}$. Maka dapat disimpulkan bahwa terdapat perbedaan peningkatan kemampuan berpikir kreatif matematik siswa berdasarkan kelompok Self-Efficacy matematis. Hal ini menginterprestasikan bahwa Self-Efficacy memiliki pengaruh terhadap kemampuan berpikir kreatif matematika siswa.

Dari hasil uji hipotesis yang telah dikemukakan sebelumnya ditemukan bahwa terdapat perbedaan kemampuan berpikir kreatif matematika siswa yang mengikuti model pembelajaran PBL dengan pendekatan saintifik dan siswa yang mengikuti model pembelajaran langsung dengan pendekatan saintifik. Artinya, perbedaan kemampuan berpikir kreatif matematika itu ada karena perbedaan perlakuan pembelajaran yang diberikan pada masing-masing kelas. Dalam hal ini dapat dikatakan bahwa model pembelajaran PBL dengan pendekatan saintifik lebih baik dalam hal meningkatkan kemampuan berpikir kreatif matematika siswa dibandingkan dengan model pembelajaran langsung dengan pendekatan saintifik khususnya pada materi bangun datar segi empat. Berikut ini akan dibahas secara umum model pembelajaran terhadap kemampuan berpikir kreatif matematika siswa ditinjau dari Self-Efficacy.

Berdasarkan hasil penelitian menunjukkan perbedaan kemampuan berpikir kreatif matematika berdasarkan model pembelajaran ditinjau dari SelfEfficacy siswa. Pada kelompok siswa dengan kategori Self-Efficacy tinggi yang mendapat model pembelajaran PBL dengan pendekatan saintifik memperoleh rata-rata $\mathrm{N}$-Gain kemampuan berpikir kreatif matematika sebesar 0.46 lebih besar dibandingkan dengan rata-rata kemampuan berpikir kreatif matematika siswa yang mendapat model pembelajaran langsung yaitu sebesar 0.30. Pada kelompok siswa dengan Self-Efficacy sedang yang mendapat model pembelajaran PBL dengan pendekatan Saintifik memperoleh rata-rata $N$-Gain kemampuan berpikir kreatif matematika sebesar 0.31 lebih besar dibandingkan 
dengan rata-rata $N$-Gain kemampuan berpikir kreatif matematik siswa yang mendapat model pembelajaran langsung yaitu sebesar 0.24. Pada kelompok siswa dengan Self-Efficacy rendah yang mendapat model pembelajaran PBL dengan pendekatan Saintifik memperoleh rata-rata $N$-Gain kemampuan berpikir kreatif matematika sebesar 0.25 lebih besar dibandingkan dengan rata-rata $N$ Gain kemampuan berpikir kreatif matematika siswa yang mendapat model pembelajaran langsung dengan pendekatan saintifik yaitu sebesar 0.19. Berdasarkan uraian tersebut di atas, dapat disimpulkan bahwa terdapat pengaruh model pembelajaran $\mathrm{PBL}$ dengan pendekatan saintifik terhadap kemampuan berpikir kreatif matematika siswa ditinjau dari SelfEfficacy.

Hasil penelitian juga menyimpulkan bahwa secara umum terdapat perbedaan yang signifikan peningkatan kemampuan berpikir kreatif matematika siswa antara kelas yang mengikuti model pembelajaran PBL dengan pendekatan Saintifik dan kelas yang mengikuti model pembelajaran langsung dengan pendekatan Saintifik ditinjau dari Self-Efficacy.

Pada dasarnya model PBL dalam pembelajaran matematika bertujuan menciptakan suasana pembelajaran agar siswa memperoleh pengalaman dalam menemukan sesuatu yang baru melalui proses pembelajaran. Tujuan pembudayaan pembelajaran matematika dengan PBL adalah membantu mengembangkan aktivitas dan berpikir matematik siswa secara serempak dalam pemecahan masalah. Menurut Amir (2009: 85), proses PBL bukan semata-mata prosedur.Tetapi ia adalah bagian dari belajar mengelola diri sebagai sebuah kecakapan hidup (life skills). Proses PBL sebagai salah satu bentuk pembelajaran yang learner centered, memandang bahwa tanggung jawab harus kita kenali dan kita pegang.
Faktor model pembelajaran yang digunakan guru berpengaruh signifikan terhadap kemampuan berpikir kreatif matematis siswa ditinjau dari Self-Efficacy serta aktivitas siswa selama mengikuti proses pembelajaran. Pada model pembelajaran langsung, guru merupakan sentral dari kegiatan proses pembelajaran dan membuat siswa berperan pasif. Akibatnya siswa menjadi kurang tertarik terhadap materi yang diajarkan, tidak menumbuh kembangkan rasa keingin tahu siswa terhadap materi yang dipelajari, siswa merasa bosan dan berharap proses pembelajaran segera berakhir sehingga kurang mampu dalam mengembangkan kemampuan berpikir kreatif matematis siswa. Hal ini dapat di lihat dari hasil penelitian yang telah di paparkan sebelumnya bahwa kemampuan berpikir kreatif matematis siswa yang mendapat model pembelajaran langsung dengan pendekatan Saintifik lebih rendah daripada siswa yang mendapat model PBL dengan pendekatan Saintifik. Dalam proses pembelajaran dengan menggunakan model pembelajaran langsung terhadap kemampuan berpikir kreatif matematis siswa tidaklah mudah dilakukan. Oleh karena itu, dibutuhkan suatu model PBL dengan pendekatan Saintifik yang memudahkan siswa melakukan suatu proses kemampuan berpikir kreatif matematis siswa merupakan sentral dalam proses pembelajaran, memfasilitasi siswa untuk melakukan penemuan sehingga siswa tertarik dalam mengikuti proses pembelajaran.

Jika dilihat dari karakteristik model pembelajaran PBL dengan pendekatan Saintifik, sebagaimana telah dijelaskan sebelumnya kondisi ini dimungkinkan terjadi. Siswa yang mendapat model PBL dengan pendekatan Saintifik belajar secara kelompok melalui proses penyelidikan permasalahan. Pada proses penyelidikan masalah tersebut, siswa menggunakan segala potensi yang dimilikinya untuk memecahkan masalah yang diberikan baik 
secara mandiri maupun secara kelompok untuk diajukan pada diskusi kelas. Ketika siswa mendapat masalah dalam proses pemecahan masalah tersebut, mereka mengemukakan pertanyaan kepada guru atau kepada siswa lain untuk memperjelas masalah dari tugas yang diberikan. Pada saat yang sama, siswa dapat saling berbagi, mempertahankan, atau menghargai pendapat atau ide-ide pemecahan masalah yang dikemukakan oleh siswa lain.

Kegiatan ini dapat mengembangkan proses berpikir pemahaman siswa terhadap masalah matematika yang diberikan sehingga dapat mempermudah siswa menemukan apa yang dicari untuk memecahkan masalah tersebut. Hal ini sesuai dengan pendapat (Wena, 2009: 138139), bahwa untuk meningkatkan

\section{KESIMPULAN DAN SARAN}

Berdasarkan hasil penelitian dan pembahasan, maka kesimpulan dalam peneleitian ini adalah sebagai berikut.

1. Terdapat peningkatan kemampuan berpikir kreatif matematik siswa yang diajar dengan model pembelajaran PBL dengan mengunakan pendekatan Saintifik dan siswa yang diajar dengan model pembelajaran langsung dengan mengunakan pendekatan Saintifik ditinjau dari Self-Efficacy matematis siswa, sehingga dapat dikatakan bahwa adanya pengaruh model pembelajaran PBL dengan mengunakan pendekatan Saintifik terhadap peningkatan berpikir kreatif matematik siswa ditinjau dari Self-Efficacy matematis siswa.

2. Terdapat perbedaan rata-rata peningkatan kemampuan berpikir kreatif matematik antara siswa yang diajar dengan model pembelajaran PBL mengunakan pendekatan Saintifik dan siswa yang diajar dengan model pembelajaran langsung mengunakan pendekatan Saintifik khusus siswa yang memiliki Self-Efficacy matematis tinggi, sehingga dapat dikatakan bahwa kreativitas siswa dapat dilakukan dengan Mendorong siswa untuk kreatif (tell student to be creative), Mengajari siswa beberapa metode untuk menjadi kreatif (teach student some creativitymethods), dan Menerima ide-ide kreatif yang dihasilkan siswa (accept the result of creative exercises). Dalam usaha meningkatkan agar siswa menjadi kreatif (tell student to be creative) dapat dilakukan dengan beberapa cara, antara lain; Mengembangkan beberapa pemecahan masalah yang kreatif untuk suatu masalah, Memberikan beberapa cara dalam memecahkan suatu masalah, dan membuat daftar beberapa kemungkinan solusi untuk suatu masalah, dan keterlibatan siswa dalam menyelesaikan masalah serta keterampilan untuk belajar secara mandiri maupun kelompok.

adanya pengaruh model pembelajaran PBL dengan pendekatan Saintifik terhadap peningkatan kemampuan berpikir kreatif matematik siswa khusus yang memiliki Self-Efficacy matematis tinggi. Sedang dan rendah

Berdasarkan kesimpulan di atas, maka peneliti menyarankan beberapa hal berikut.

1. Kemampuan berpikir kreatif matematis siswa adalah salah satu ketrampilan proses berpikir yang perlu dikembangkan untuk menumbuhkan kreatifitas siswa dalam penyelesaian masalah atau mencari alternatif solusi penyelesaian masalah, memiliki pemikiran terstruktur, baik dalam pembelajaran matematika maupun dalam kehidupan sehari-hari.

2. Dengan melihat pencapaian yang diperoleh dalam penelitian ini, model PBL dengan pendekatan Saintifik dapat dijadikan sebagai alternatif model pembelajaran dalam meningkatkan kemampuan berpikir kreatif matematis, namun perlu mempertimbangkan beberapa hal, yakni kecukupan waktu 
dalam pembelajaran, ketersediaan sumber belajar yang beragam, kesiapan siswa dan guru.

3. Guru perlu memperhatikan bahwa walaupun pelaksanaan model PBL dengan pendekatan Saintifik telah terlaksana dengan baik tetapi belum dapat memenuhi standar kriteria ketuntasan minimal matematika di sekolah. Jadi, untuk dapat meningkatkan kemampuan berpikir kreatif matematis siswa di sekolah.

\section{DAFTAR PUSTAKA}

Amir, M.T. 2009. Inovasi Pendidikan Melalui Problem Based Learning. Jakarta: Kencana Prenada Media Group.

Bandura, A. 1997. Self-efficacy: The exercise of control. New York, NY: W.H. Freman and Company.

Herman, T. 2007. Pembelajaran Berbasis Masalah untuk Meningkatkan Kemampuan Berpikir Matematis Tingkat Tinggi Siswa Sekolah Menengah Pertama. Educationist Journal, I (I).

Hidayat, S.U. 2011 Model-Model Pembelajaran Berbasis Paikem. Bandung: CV Siliwangi \& CO .

Wena. 2009. Strategi Pembelajaran Inovatif Kontemporer: Suatu Tinjauan Konseptual Operasional. Jakarta: PT. Bumi Aksara. maka perlu diperhatikan faktor lain dari siswa seperti Self-Efficacy (kepercayaan diri siswa) dalam pelaksanaan pembelajaran.

4. Guru perlu melatih siswa dengan soalsoal yang berisi indikator-indikator kemampuan berpikir kreatif matematis siswa dalam pembelajaran di kelas agar kemampuan siswa lebih terlatih dalam menyelesaikan masalah matematika 